\title{
Salvação, acolhida do ser humano e a obra do Espírito Santo
}

David Mesquiati de Oliveira

\section{Resumo}

Trata-se de uma reflexão teológico-pastoral. A questão de fundo é como comunicar a fé em Jesus Cristo e sua salvação a um mundo secularizado e/ou pluralista. Está baseada em uma teologia da criação atrelada a uma teologia da salvação, bem como de um conceito mais abrangente de revelação e a consequente acolhida do ser humano, considerando que Deus age em todas as culturas. No entanto, a cultura não tem capacidade de expressar por si mesma essa ação salvífica, necessitando descobrir no cultural a referência a Deus. O texto busca sustentar uma teologia simultaneamente do diálogo e do anúncio. Assume a universalidade da salvação e da obra do Espírito Santo em todas as culturas, mas não a desvincula da tradição judaico-cristã. No encontro de culturas, uma aporta à outra, e todas são alteradas. Além disso, todo encontro de culturas é também um encontro de religiões. Inculturar a fé cristã é também dialogar com outras religiões. Nesse sentido, a prática missionária deve voltar-se para descobrir Jesus Cristo nos diferentes povos, a partir do Espírito de Cristo. A atitude fundamental (sair-de-si-próprio) abre novos horizontes e possibilita emergir um Cristo que convida à conversão em cada povo (etnia), falando sua linguagem e expressando-se como eles.

Palavras-chave: Cultura - Evangelho - Anúncio - Diálogo. 


\section{Resumen}

Se trata de una reflexión teológico-pastoral. La línea de fondo es cómo comunicar la fe en Jesucristo y su salvación a un mundo secularizado y/o pluralista. Se basa en una teología de la creación unida a una teología de la salvación, así como un concepto más amplio de la revelación y la posterior aceptación del ser humano, mientras que Dios obra en todas las culturas. Sin embargo, la cultura no es capaz de expresar esta acción salvífica, que requiere descubrir la referencia a Dios en lo cultural. El texto tiene como objetivo apoyar al mismo tiempo una teología del diálogo y la proclamación. Asume la universalidad de la salvación y el Espíritu Santo en todas las culturas, pero requiere la tradición judeo-cristiana. En el encuentro de las culturas, una aporta a la otra, y todas cambian. Además, cada encuentro de culturas, es también un encuentro de las religiones. Inculturar la fe cristiana, es también dialogar con otras religiones. En este sentido, la práctica misionera debe descubrir Jesucristo en distintas culturas, desde el Espíritu, que es el de Cristo. La actitud básica (salir-de-uno-mismo) abre nuevos horizontes y permite la aparición de un Cristo que invita a la gente a la conversión en cada grupo étnico, hablando su lengua y expresándose como ellos.

Palabras-clave: Cultura - Evangelio - Anuncio - Diálogo.

\section{Introdução}

A motivação para a reflexão sobre a temática em questão é de ordem pastoral. Como comunicar a fé em Jesus Cristo e sua salvação a um mundo secularizado e, quando religioso, pluralista? Qual o específico da salvação de Jesus Cristo e por que é universal? Tomamos, como base, principalmente as contribuições de três teólogos católicos: Mario de França Miranda, Luiz F. Ladaria, Alfonso Garcia Rubio e de dois teólogos protestantes, Jüngen Moltmann e Gustaf Aulén. As implicações missiológicas se alicerçam a partir das reflexões de David Bosch.

A universalidade da salvação está dada a partir da correta compreensão de quem é Deus, pois, em última instância, a salvação do ser humano é o próprio Deus ${ }^{1}$. Baseado em uma teologia da criação atrelada a uma teologia

\footnotetext{
${ }^{1}$ MIRANDA, M. F. A salvação de Jesus Cristo: a doutrina da graça. São Paulo: Loyola, 2004, p. 20.
} 
da salvação, bem como de um conceito mais abrangente de revelação e a consequente acolhida do ser humano, consideramos que Deus age em todas as culturas. No entanto, a cultura não tem capacidade de expressar por si mesma essa ação salvífica, necessitando descobrir no cultural a referência a Deus². Veremos adiante essa dinâmica, e indicações de como sustentar uma teologia simultaneamente do diálogo e do anúncio.

\section{A universalidade da salvação}

A relação estreita entre criação e salvação nas Escrituras acabou sendo insuficientemente articulada na reflexão teológica cristã. Ao longo dos últimos séculos, predominando o dualismo, a salvação foi separada da criação ${ }^{3}$. Apesar de a criação cronologicamente vir primeiro, é a salvação quem deve receber o primeiro lugar teologicamente ${ }^{4}$. Isto implica que a teologia da criação não pode ser concebida isolada da soteriologia, afinal, elas provêm de uma mesma fonte.

Uma correta e adequada teologia da criação pode, ainda, desfazer o dualismo vigente em muitos círculos entre fé e cultura. Como nesses casos a reflexão parte de uma origem ontológica da criação como realidade neutra, a oferta salvífica de Deus é algo que se acrescenta ${ }^{5}$. Carecendo de fundamentação bíblica, essa visão resulta em muitas distorções. Se a ênfase recair sobre o ato da criação de Deus então poderíamos inferir:

(a) que Deus normalmente atua sozinho no esplendor divino solitário, como ele deve ter feito em criar o mundo do nada; $(b)$ que Deus realiza imediatamente o que ele decide e é conhecido acima de tudo pela sua onipotência; $(c)$ que Deus atua dentro de situação perfeita, uma vez que ele não pode produzir coisa alguma indigna $[\ldots] ;(d)$ que os detalhes da ação criadora de Deus através do universo podem ser medidos por instrumentos científicos; (e) que o primeiro ato criador de Deus é único e jamais pode ser repetido ${ }^{6}$.

\footnotetext{
${ }^{2}$ MIRANDA, M. F. Inculturação da fé: uma abordagem teológica. São Paulo: Loyola, 2001, p. 100.

${ }^{3}$ RUBIO, A. G. Unidade na pluralidade: o ser humano à luz da fé e da reflexão cristãs. 5 ed. São Paulo: Paulus, 2011, p. 115s, especialmente o capítulo 3.

${ }^{4}$ SENIOR, D. \& STUHLMUELLER, C. Os fundamentos bíblicos da missão. Santo André: Academia Cristã; São Paulo: Paulus, 2010, p. 62.

${ }^{5}$ Incongruência corretamente apontada em MIRANDA, Inculturação da fé, p. 92s.

${ }^{6}$ SENIOR \& STUHLMUELLER, Os fundamentos bíblicos da missão, p. 63.
} 
Ao contrário desse modelo baseado numa versão da criação, as Escrituras apresentam um Deus que age no decorrer da história humana e, dessa forma, não atua sozinho, mas dentro de elaborada rede humana de política, economia e costumes sociais. Senior \& Stuhlmueller nos brindam com a seguinte síntese acertada: "Deus não nos impressiona tanto com o seu poder, quanto com a misericórdia e a sua tolerância com a fraqueza humana, a ignorância e até o pecado deliberado" e continuam, "o cenário da ação de Deus já não é a arena aberta, desimpedida do nada [...] mas é a água lamacenta e a atmosfera poluída da vida humana"7. Acrescenta-se que os grandes atos redentores de Deus podem ser repetidos reiteradas vezes e que Seu amor motivador (Ef 3.18) não pode ter altura e profundidade determinada, sendo Sua ação incomensurável.

Estamos lidando com a disposição de Deus em ocupar-se com a situação complicada da vida humana em suas diferentes culturas. Um Deus que se faz conhecido como salvador. Na história bíblica, somente resgatando o seu povo é que Deus se manifestou como criador. E essa salvação é uma recriação. Tanto o relato da criação como o da redenção manifestam o desejo de Deus de ver sua criação salva. Porque Ele planejou a humanidade para o bem, é que existiu a criação. Uma vez o ser humano caído, Ele intervém como salvador. Mantém-se o padrão primeiro, e evidencia-se o caráter salvífico da ação de Deus.

Há uma iniciativa de Deus, uma proposta que aguarda uma resposta dos seres humanos. Essa resposta ao Último constitui-se na experiência primeira. Ela difere das tematizações posteriores e "mesmo uma autêntica experiência mística pode ser entendida e verbalizada correta ou incorretamente, suficiente ou insuficientemente"8. Mas, mesmo que não consigamos dar uma explicação racional satisfatória para a ação de Deus no ser humano e na história, Ele continua se doando aos povos. Seu agir salvífico acontece por iniciativa do próprio Deus, que vem ao encontro do homem. Como afirma Miranda, a salvação consiste exatamente nesse encontro ${ }^{9}$. Nesse sentido, o ser humano foi criado para o encontro com Deus. Isto é, a ordem da criação está envolvida pela ordem da salvação. Por natureza a salvação cristã se dirige a toda humanidade, tendo uma dimensão universal.

No entanto, "a salvação cristã só poderá ser entendida e assumida como tal se conseguir ser experimentada e expressa no interior de cada cultura"10.

\footnotetext{
${ }^{7}$ SENIOR \& STUHLMUELLER, Os fundamentos bíblicos da missão, p. 64.

${ }^{8}$ MIRANDA, Inculturação da fé, p. 71.

${ }^{9}$ MIRANDA, Inculturação da fé, p. 72.

${ }^{10}$ MIRANDA, A salvação de Jesus Cristo, p. 26.
} 
Temos, então, uma inculturação da fé como inculturação da salvação de Jesus Cristo. Assim está posto o objetivo pastoral da Igreja:

Devemos afirmar mais corretamente que a função última da Igreja, enquanto Povo de Deus e comunidade dos cristãos, é levar outras gerações a realizarem as experiências salvíficas que deram sentido e unidade à existência de seus membros. Ela transmite não só enunciados ou doutrinas, mas sobretudo experiências salvíficas, resultantes do encontro com Jesus Cristo vivo ${ }^{11}$.

Essas experiências salvíficas apontam para o fato de que a vivência autêntica da fé cristã tem necessariamente uma dimensão social e política que lhe é intrínseca. Em Atos 15 está registrado um episódio envolvendo Paulo, Silas, Barnabé e outros cristãos na Igreja em Jerusalém, onde as experiências salvíficas foram condicionadas a uma versão cultural particular. Ainda que tal atitude tenha sido desautorizada no desfecho do mesmo capítulo, a tendência continuou viva nos séculos seguintes ${ }^{12}$.

Um grupo de cristãos achou que deveria permanecer fechado em seu mundo cultural. Aceitavam que os gentios podiam receber a salvação cristã, mas primeiramente deveriam aceitar a lei de Moisés, a circuncisão, etc. Nesse modelo "os outros" é que devem vir até a Igreja. O outro modelo defendido na ocasião, no entanto, era instigante:

Bem diferente é a atitude evangelizadora de Paulo e dos primeiros grandes evangelizadores. Eles não ficam instalados, esperando que os outros se aproximem: saem do ambiente familiar palestinense e vão ao encontro dos gentios, lá onde eles estão, em seu mundo cultural. O objetivo é ajudar os outros a encontrarem, no interior de seu mundo, um Jesus Cristo vivo, capaz de tocar seu coração no processo de conversão, um Jesus capaz de falar a linguagem e de movimentar a afetividade do grego, do romano, e assim por diante ${ }^{13}$.

O prolongamento dessa lógica implica em uma evangelização inculturada que procura ser africano com os africanos, japonês com os japoneses, andino com os andinos, com o objetivo de ganhá-los para Cristo (um Cristo

\footnotetext{
${ }^{11}$ MIRANDA, A salvação de Jesus Cristo, p. 16.

${ }^{12}$ Esse exemplo foi explorado em RUBIO, A. G. O encontro com Jesus Cristo vivo: um ensaio de cristologia para nossos dias. 14 ed. São Paulo: Paulinas, 2010, p. $183 \mathrm{~s}$.

${ }^{13}$ RUBIO, O encontro com Jesus Cristo vivo, p. 183.
} 
japonês ou andino) e não para uma determinada cultura (no caso, a ocidental) ${ }^{14}$. Tal modelo está inspirado em Jesus, cuja atitude fundamental "resume-se no desprendimento, na saída-de-si-próprio para encontrar o outro onde estiver, a fim de ajudá-lo em seu crescimento" 15 .

A história da evangelização da América Latina, no entanto, mostra que esse modelo crístico não foi observado. Antes, porém, prevaleceu um tipo de cristianismo centralizador de matriz ocidental, que influiu decisivamente sobre as experiências salvíficas realizadas e tematizadas em outros horizontes socioculturais. A decisão de nivelar as demais experiências a partir do próprio, sobre o pretexto de unidade, revelou que o que se pretendia era de fato a unanimidade ou unicidade de pensamento e tematização. Contudo, "para manter sua identidade em outros contextos, a experiência salvífica cristã deve ser vivida e expressa diversamente" ${ }^{\prime 16}$. Nesse sentido:

Faltou, com lamentável frequência, a atitude fundamental, vivida por Jesus Cristo: sair-de-si-próprio para encontrar o índio, o negro, o povo marginalizado, em seu mundo, em sua cultura, em sua expressividade. Encontrá-los para aprender com eles e assim poder ajudá-los na descoberta de um Jesus Cristo que já está no coração dessa gente (universalidade da graça da redenção de Jesus Cristo). A evangelização é vista, assim, como um serviço humilde e discreto, que ajuda a emergir esse Cristo com os traços do índio, do negro..., que fala a linguagem deles e que toca seu coração, convidando-os à conversão ${ }^{17}$.

A diversidade está dada já na criação, nas variações do mundo animal e vegetal, nas disposições climáticas etc. Por conseguinte, não é possível reduzir todo o espectro humano a uma única versão cultural. E mais, essa diversidade é uma riqueza, não um prejuízo ou contratempo. Dado que as culturas humanas são tão distintas entre si, não basta falar de teologia da criação. É preciso associar a dimensão da revelação nas diferentes culturas.

Por revelação entendemos o gesto gratuito de Deus de se manifestar a nós para nossa salvação. Ela acontece na própria doação que Deus faz de si mesmo, como um convite a participarmos da vida de Deus. "Revelação cristã não significa primeira e fundamentalmente um saber sobre Deus", afirma

\footnotetext{
${ }^{14}$ Cf. RUBIO, O encontro com Jesus Cristo vivo, p. 184.

${ }^{15}$ RUBIO, O encontro com Jesus Cristo vivo, p. 183.

${ }^{16}$ MIRANDA, Inculturação da fé, p. 64, grifos do texto.

${ }^{17}$ RUBIO, O encontro com Jesus Cristo vivo, p. 185.
} 
Miranda. E, no espírito do Vaticano II, registra-se que "um encontro salvífico de Deus com o ser humano, [visa] primariamente não à transmissão de verdades, e sim à comunicação de vida e salvação" ${ }^{18}$. Nesse sentido, revelação de Deus e realização da salvação se equivalem.

Embora a ação salvífica de Deus tenha uma dimensão cognitiva, a revelação não é a transmissão de um ensinamento divino que serve à salvação. Não se constitui de verdades reveladas ou formulações da fé. Tal equívoco tem gerado um cristianismo racionalizado, frio e impessoal. Ao contrário, a revelação diz respeito à intervenção salvífica de Deus, experimentada e manifestada por seu povo. Portanto, criativa, diversificada e humanizadora:

Nós cristãos devemos superar nosso etnocentrismo cultural e principalmente a centração em nossa própria experiência de revelação, que nos faz arrogantes e pretensos detentores do monopólio da verdade revelada e dos meios de salvação. Ao contrário, todos estamos no seio da verdade e todos podemos crescer na aproximação e na apropriação pessoal e coletiva dessa verdade [...] Todos podemos aprender uns dos outros acerca dessa verdade $\mathrm{e}$ nos corrigir dos equívocos e desacertos que cometemos contra ela ${ }^{19}$.

Deus se doa continuamente em graça e perdão a todos os seres humanos, em todos os momentos da história. "Deus não chegou aqui com os missionários. Ele já estava presente nas culturas: a revelação não se restringiu à experiência judaico-cristã, recolhida canonicamente pelas Escrituras. Mas é um dado permanente da história da salvação universal" ${ }^{20}$. Mas todo esse esforço de Deus implica que o ser humano capte e experimente de algum modo essa ação de Deus. Caso contrário não poderíamos falar de revelação salvífica ${ }^{21}$.

Nesse sentido, temos duas questões importantes a considerar. A primeira é a liberdade do ser humano em sua resposta a Deus. Um evangelho sem liberdade e sem libertação não é o evangelho de Jesus nem o anunciado pelos apóstolos. A segunda, é que o acolhimento na fé é parte constitutiva da realidade da revelação de Deus. Essas duas questões concorrem para a meta da autocomunicação de Deus.

Se as religiões são respostas de todo um povo, coletivamente, à proposta de Deus, a teologia daí resultante tem como sujeito a própria comunidade.

\footnotetext{
${ }^{18}$ MIRANDA, Inculturação da fé, p. 65.

${ }^{19}$ BOFF, L. América Latina: da conquista à nova evangelização. São Paulo: Ática, 1992, p. 43.

${ }^{20}$ BOFF, América Latina, p. 38.

${ }^{21}$ MIRANDA, Inculturação da fé, p. 66.
} 
De acordo com Leonardo Boff, isso é assim, ao menos para a teologia indígena, em curso em nosso continente ${ }^{22}$. Como vimos, essa resposta pode ser insuficiente ou incorretamente entendida e verbalizada. Em sua liberdade, o homem pode escolher perder-se. E mesmo que tenha decidido corretamente, há o risco de não-acolhida. Como a fé resulta da própria ação de Deus, a acolhida em fé é parte integrante do que é a Palavra de Deus. Sem o acolhimento, não podemos dizer que houve revelação. A fé é o que nos possibilita captar essa interpelação.

Como consequência direta disso, podemos afirmar que a revelação salvífica de Deus não poderia prescindir da Igreja. Como comunidade dos que creem, o ser Igreja capta e experimenta a ação de Deus de modo privilegiado. A Igreja de Deus não é uma instituição, nem uma "igreja invisível". É a comunidade dos que acolhem na fé a ação salvífica de Deus e que transmite, sobretudo, experiências salvíficas. Esse acolhimento nos afeta profundamente, pois da Igreja vem à existência no seguimento de Jesus Cristo vivo:

Dado central de nossa fé é o fato de que Deus interveio em nossa história por seu Filho Jesus Cristo, constituindo esta iniciativa absolutamente livre de Deus uma interpelação para nós. Acolhendo-a, deixando que polarize, hierarquize e estruture todas as dimensões de nossa pessoa, respondemos ao gesto gratuito de Deus, assumimos o sentido último de nossa existência, dispomos de uma referencia para o agir, concebemos nossa história como um projeto a ser realizado, numa palavra, vivemos como cristãos. [...] Atingindo-nos profundamente, esse envolvimento com o convite divino torna-se uma experiência totalizante, que ilumina e estrutura a multiplicidade de experiências que constituem nossa história pessoal ${ }^{23}$.

Essa salvação não está ausente nos diferentes povos no mundo. A concepção tradicional de missão - levar a salvação cristã - perde sua força, mas a atividade missionária não perde seu sentido. Antes, precisa se readequar. Para isso, cabe uma reflexão sobre quem pode mediar essa salvação e qual é o específico da salvação cristã. Apontamentos nessa direção serão feitos a seguir.

\footnotetext{
${ }^{22}$ BOFF, América Latina, p. 38.

${ }^{23}$ MIRANDA, A salvação de Jesus Cristo, p. 16.
} 


\section{A mediação cristológica}

Depois de considerarmos que a salvação é universal, que Deus se revela a todos os povos e culturas e que sua revelação é por definição salvífica, vamos nos deter sobre o específico da salvação cristã. A fé cristã considera Cristo o centro da revelação divina. Ao mesmo tempo, toda fé cristã é fé em Deus. Não é fé em algo além de Deus, mas fé em um Deus que se encarnou em Cristo, definindo a relação cristã com Deus e o conceito cristão de Deus. O problema potencial implícito aqui - escolher a teocentricidade ou a cristocentricidade pode ser evitado assumindo-se que "a fé cristã é cristocêntrica precisamente porque é profundamente teocêntrica" ${ }^{24}$. Vamos considerar agora as implicações dessa mediação cristológica para o encontro entre o cristianismo e as outras religiões.

A fé cristã não admite outro mediador a não ser Jesus Cristo. Ele é único e universal. Sua mediação é superior às demais ( $\mathrm{Hb} 8.6$; 9.15; 12.24). Tais exigências têm ensejado debates ao longo da história, e não apenas nos atuais tempos pós-modernos. Não se pretende circunscrever a revelação divina, mas trata-se de não reconhecer outro Deus a não ser o que se revelou em Cristo. Ele não é uma etapa a ser superada ${ }^{25}$, e outros mediadores não poderiam coexistir, pois não há o que complementar. Jesus é o perfeito Mediador porque a "salvação" que comunica ao ser humano é a Sua mesma. Em sua humanidade, recebeu-a do Pai, e a quer compartilhar com todos os homens ${ }^{26}$ : "Ele é o único que, padecendo por todos, dá a todos a universalidade do gênero humano, a vida e a salvação" 27 . Agora Ele é a salvação. Como salvador único, sua salvação alcança o gênero humano, por certo também aqueles que estão em outras religiões: "Pois não há, debaixo do céu, outro nome dado aos homens pelo qual devamos ser salvos" (At 4.12).

O ser humano não pode salvar-se (autossoteriologia). E a salvação supõe que intervenha uma alteridade. Essas duas premissas exaradas da Bíblia apontam para a solução encaminhada por Deus: promover o encontro com o humano. Deus toma a iniciativa de revelar-se (salvar) e os homens respondem a partir da fé. Entendemos fé aqui como uma expressão aplicada à relação entre Deus e o homem, e que deve ser compreendida sob dois pontos de vista: a) em ser o

\footnotetext{
${ }^{24}$ AULÉN, G. A fé cristã. 2 ed. São Paulo: ASTE, 2002, p. 64s.

${ }^{25}$ LADARIA, L. F. Jesucristo, salvación de todos. Madrid: San Pablo, 2007, p. 15.

${ }^{26}$ LADARIA, Jesucristo, salvación de todos, p. 116.

${ }^{27}$ LADARIA, Jesucristo, salvación de todos, p. 145.
} 
homem submetido e dominado por Deus - fundamenta-se na atividade de Deus e existe em razão dela ; e b) do ponto de vista humano - apresenta-se como um voltar-se e entregar-se a Deus. A fé implica sempre em escolha e decisão. Nesse sentido, a revelação é anterior à fé. Deus provoca uma resposta. Paradoxalmente, a fé origina-se e nutre-se da revelação. São conceitos correlatos ${ }^{28}$.

O diferencial é a iniciativa de Deus, mas o sim do homem é importante. Sem acolhida não houve efetivamente revelação. Uma consequência para a sintonia do gesto redentor de Deus e a entrega do homem é sua divinização, no sentido da ação de Deus no homem: temos o novo nascimento, renovação da mente, união com o Pai, com Cristo, o agir sobrenatural do Espírito Santo, etc. No entanto, essa nova relação dialogal entre Deus e o homem não se funde em outro ser, isto é, o homem permanece plenamente homem, frente a um Deus distinto dele. O ser humano é resgatado do seu estado de morte e elevado (dignidade), passa a ter vida, no sentido amplo da palavra.

Mas isso não acontece indistintamente. A revelação não é captada igualmente por todos. Muitas culturas desenvolveram suas respostas às provocações de Deus e muitas vezes foram ineficazes. As religiões podem ser expressão do egoísmo e da limitação humana. Nem por isso elas estão descartadas e, por definição, consideradas errôneas ou demoníacas - especialmente o que se atribuiu às religiões indígenas. As religiões não-cristãs são legítimas, no sentido de ser o meio de que os indivíduos dispõem para responder a Deus. Contudo, não constituem alternativas possíveis ao cristianismo. Ainda assim, nelas também ocorrem eventos salvíficos porque a ação do Espírito pode ser captada por caminhos que desconhecemos. De qualquer forma, é Cristo quem salva. Não há outro mediador. ${ }^{29} \mathrm{E}$ isso não precisa ser um empecilho para o diálogo inter-religioso:

Afirmar ser Jesus Cristo a verdade última de Deus não significa que tenhamos já a compreensão e a expressão definitiva dessa mesma verdade. Nosso conhecimento é sempre fragmentário e imperfeito, contextualizado e limitado. Portanto suas expressões devem estar abertas a ulteriores correções e aperfeiçoamentos. Schillebeeckx chega a admitir aspectos verdadeiros, bons e belos de experiências com Deus que não conseguem encontrar sua expressão na experiência religiosa transmitida pelo cristianismo. $^{30}$

\footnotetext{
${ }^{28}$ AULÉN, A fé cristã, p. $39 \mathrm{~s}$.

${ }^{29}$ MIRANDA, A salvação de Jesus Cristo, p. 213s.

${ }^{30}$ MIRANDA, M. F. O cristianismo em face das religiões. São Paulo: Loyola, 1998, p. 70.
} 
Nesse sentido, Claude Geffré acentua a limitação do cristianismo como religião histórica:

Quando falamos em termos de singularidade ou de unicidade, é preciso tentar refletir no que pode ser uma unicidade relativa em relação a uma unicidade de excelência ou de integração. E é aí que é urgente repensar de uma forma nova a noção de cumprimento. É verdade que Cristo cumpriu todas as coisas, mas eu não diria que o cristianismo como religião histórica cumpriu todas as outras religiões. ${ }^{31}$

O encontro com as demais religiões, então, não pode condená-las totalmente. Tampouco pode validá-las acriticamente. Há um critério definitivo capaz de discernir nas expressões religiosas o que corresponde à ação do Espírito. Esse critério, Jesus Cristo, as outras religiões não têm. Para ser autêntico, o cristianismo não pode desprender-se desse critério. Ele está guiado pela atitude fundamental de obediência ao Pai e de entrega aos seres humanos. França Miranda afirma que foi essa atitude fundamental que trouxe salvação a Jesus, pois, motivado por isso, o Pai o ressuscitou ${ }^{32}$. E o Espírito nos leva a assumir a vida de Jesus para que cheguemos à salvação definitiva. Toda a ação do Espírito é de nos fazer "outros Cristos", "outros Filhos" (Rm 8.14-16; Gl 4.6) ${ }^{33}$ :

Contudo, a fé cristã reafirma que outros reveladores são sempre penúltimos, pois, devido à limitação (estruturalmente) eà pecaminosidade (historicamente) inerentes à condição humana, podem estar a absolutizar não a realidade última, mas projeções de seus próprios interesses. O que também vale para as figuras bíblicas que precederam Jesus Cristo, que nem por isso deixaram de atuar como manifestações e mediações da salvação de Jesus Cristo, já que a fé cristã não reconhece outra. ${ }^{34}$

É necessário comunicar a mensagem de um Jesus universal pré-existente justamente porque não damos por certo que todos estejam captando corretamente a revelação. A tarefa missionária consiste em inculturar a fé cristã nesses diferentes contextos, a partir do respeito e da solidariedade universal

\footnotetext{
${ }^{31}$ GEFFRÉ, C. Crer e interpretar: a virada hermenêutica da teologia. Petrópolis: Vozes, 2001, p. 169.

${ }^{32}$ MIRANDA, A salvação de Jesus Cristo, p. 148.

${ }^{33}$ MIRANDA, A salvação de Jesus Cristo, p. 171 e 210.

${ }^{34}$ MIRANDA, O cristianismo em face das religiões, p. 67.
} 
da humanidade. Mas não quer dizer que antes dos missionários a salvação de Jesus não lhes podia alcançar. Paulo declara que Deus não se deixou ficar sem testemunho de si mesmo entre os gentios (Rm 1.14-15; At 14.17). Antes, porém, afirmamos que essa revelação dá-se de modo pleno em Jesus. Por isso é preciso conhecê-Lo, enquanto vida, obra e ensino.

Como acertadamente observou Walter Sass, as três formas tradicionais de diálogo inter-religioso - o exclusivismo, o inclusivismo e o pluralismo - não satisfazem plenamente, sobretudo quando testadas do ponto de vista do respeito pelo outro e da própria fé. As limitações podem ser apontadas: o exclusivismo seria da ordem da imposição, negando qualquer verdade do outro; o inclusivismo seria seletivo, pois reconhece apenas algumas verdades no outro; e o pluralismo, que parece ser o que mais leva em consideração o outro, no fundo é indiferente, pois não teria critérios para as (in)verdades de cada religião ${ }^{35}$.

Gustaf Aulén argumenta que "a vontade divina se patenteia no contexto da revelação na qual Cristo surge como Aquele que encarna Deus e leva a bom termo sua vontade redentora". E prossegue:

Essa formulação abrange dois pontos de vista fundamentais em particular. Em primeiro lugar, em Cristo está o centro absoluto da fé. Em segundo, Cristo nunca está isolado, mas coloca-se num amplo contexto que se estende, a partir dele, tanto para trás, na história antiga, como para a frente, em direção ao futuro. Tal como a conceitua a fé cristã, a revelação de Deus não é um ponto no tempo nem um ato isolado de Deus, mas sim uma série contínua de atos divinos. Deus não se limitou a falar e agir uma vez na história do mundo. ${ }^{36}$

Essa série de atos contínuos de revelação culminou em Cristo como ato decisivo e final. E não pode confundir-se "como complemento ao que já foi dado ou como acréscimo ao conhecimento de Deus já existente". O mesmo autor conclui: "Não é algo de quantitativo, mas sim de qualitativo, o que separa a revelação de Deus de ser compreendida em Cristo e sua obra, de tudo o que pudesse ser chamado de revelação divina" ${ }^{37}$. Em outras palavras, está em questão a unicidade da revelação cristã. Ela não pode ser distribuída

\footnotetext{
${ }^{35}$ W. SAAS. “O Deus trinitário está presente antes da chegada do missionário”. In: Estudos Teológicos, v. 44, n. 2 (2004) p. 73-81.

${ }^{36}$ AULÉN, A fé cristã, p. 44.

${ }^{37}$ AULÉN, A fé cristã, p. 46.
} 
parcial ou regionalmente. Em Jesus houve uma ação única de Deus. A essa ação única corresponde uma concepção única de Deus que não complementa ou ultrapassa simplesmente todos os outros, mas efetivamente os elimina. Jesus é o único Mediador e revelou um Deus único. A mediação de Jesus se baseia em sua identidade como Filho de Deus e como homem.

Jesus é o agente da reconciliação. Só Ele pode conhecer o Pai e pode revelá-lo aos outros (Jó 14.6; Mt 11.27s). Em sua encarnação, transmitiu vida ao gênero humano. Sendo Ele a Cabeça, Sua vida é transmitida a todo Corpo. O Novo Testamento aponta para a dimensão universal da salvação, relacionando-a a Jesus Cristo. E isso é assim em dois sentidos: ocupa-se com o ser humano e também com todo o mundo criado.

A dimensão universalista se dá porque todos os homens foram chamados à salvação: “[...] Deus, nosso Salvador, que quer que todos os homens sejam salvos e cheguem ao conhecimento da verdade. Pois há um só Deus e um só mediador entre Deus e os homens, um homem, Cristo Jesus, que se deu em resgate por todos [...]" (1 Tm 2.3-5). Em Apocalipse 7.9, a multidão era composta de todas as nações, tribos, povos e línguas. Ao mesmo tempo, a salvação estende-se para a renovação de todo o mundo criado: "O que nós esperamos, conforme a sua promessa, são novos céus e nova terra, onde habitará a justiça" (2 Pe 3.13; Ver Rm 8.19s). O conceito bíblico de salvação, então, tem de ser nitidamente distinguido de toda forma de gnosticismo: "A salvação não pode ser senão a negação de todo individualismo e de toda evasão espiritualista; ela só pode trazer a plena comunhão não somente com Deus, mas também com os homens e com o mundo". ${ }^{38}$

A pergunta que se suscita é como pode um evento particular na história dar um salto para a universalidade? A resposta não é simples. Iniciamos recuperando a premissa bíblica de que foi Deus quem tomou a iniciativa. E o que Ele revelou foi a Si mesmo (autocomunicação divina). Dessa forma, Jesus de Nazaré é o Filho de Deus, e quem o "vê, vê o Pai" (Jó 14.9). A resposta que o homem dá a essa iniciativa livre de Deus é a resposta à realização última da sua vida. Nesse sentido, França Miranda conclui que "a experiência que tiveram os primeiros discípulos com Jesus de Nazaré levou-os a ver nele não somente o salvador da humanidade, mas também o sentido último de toda criação". Assim, "existimos para receber em nós o próprio Deus". E continua, a partir do dado histórico (Jesus de Nazaré), chegando a "uma afirmação universal

${ }^{38}$ LACOSTE, J-Y (dir). "Salvação". In: Dicionário Crítico de Teologia. São Paulo: Paulinas e Loyola, 2004, p. 1597. 
(todo ser humano vive sob o dinamismo do amor de Deus)"39. Como afirmou Luis Ladaria: "não se podem separar o caminho e o destino"40.

A particularidade de Jesus está no fato de Ele ser Filho de Deus. Ele doa a salvação, e é o próprio dom:

Jesus Cristo não é apenas mais alguém na história que nos revela "algo" de Deus na limitação e imperfeição próprias da condição humana. Jesus Cristo é salvador, a saber, não só é mediação manifestativa ou normativa, como querem alguns, mas também constitutiva da salvação. Por ser Filho de Deus, pode ser mediador único e universal. Aqui está a especificidade da soteriologia cristã: Deus mesmo é o mediador! ${ }^{41}$

Claude Geffré concilia a particularidade histórica da revelação cristã com a mensagem de salvação universal de Jesus a partir do alcance da cruz de Cristo:

Somos, portanto, convidados a compreender a singularidade cristã à luz da cruz. [...]. A cruz tem um valor simbólico universal: ela é o símbolo de uma universalidade sempre ligada ao sacrifício de uma particularidade. Jesus morre à sua particularidade enquanto Jesus de Nazaré, para renascer em figura de universalidade, em figura de Cristo. Cabe citar aqui esta fórmula audaciosa de Paul Tillich: "Cristo é Jesus e a negação de Jesus. ${ }^{42}$

O ato divino em Cristo está acabado, mas ao mesmo tempo ele prossegue continuamente. É o Espírito quem preserva o caráter dinâmico da revelação. Com isso, ela estende-se até o fim do tempo: "a noção da revelação contínua e viva está inseparavelmente ligada à de um Deus vivo”. Ele está sempre agindo no mundo, efetivando sua vitória em cada geração ${ }^{43}$. E não podemos identificar ou confundir a revelação divina com qualquer entidade histórica ou humana. A fé cristã "considera extremamente presunçosas", afirma Aulén, "quaisquer tentativas no sentido de regular e determinar os limites dentro dos quais a revelação divina possa expressar-se". E continua: "a fé cristã, entendida corretamente, não tem o mínimo interesse em limitar e restringir o âmbito da revelação divina" 4 .

\footnotetext{
${ }^{39}$ MIRANDA, A salvação de Jesus Cristo, p. 56

${ }^{40}$ LADARIA, Jesucristo, salvación de todos, p. 15.

${ }^{41}$ MIRANDA, O cristianismo em face das religiões, p. 61.

${ }^{42}$ GEFFRÉ, Crer e interpretar, p. 167

${ }^{43}$ AULÉN, A fé cristã, p. 52.

${ }^{44}$ AULÉN, A fé cristã, p. 45.
} 
Infelizmente, "cada estrutura eclesiástica tem reduzido Cristo para encaixá-lo no seu sistema doutrinário" ${ }^{45}$. A postura de Donald Price, como de tantos outros evangélicos, denuncia esse reducionismo:

Meu medo é que sigamos o exemplo das missões católicas e protestantes conciliares à medida que abrimos mão da extra ecclesiam nulla sallus, da noção de que a salvação se encontra tão somente em Jesus Cristo. Para que vamos nos sacrificar para fazer missões se isso não faz falta, se as pessoas serão salvas mesmo sem a nossa pregação? [...] Fora da Igreja há salvação!! [sic] Em pouco tempo, a Igreja abandona uma doutrina milenar ${ }^{46}$.

Conforme aponta corretamente Antonio Carlos Barro, está no inconsciente dos cristãos e dos missionários que o mundo clama pela presença $d a$ Igreja. Afirmam: "O mundo clama por batistas, presbiterianos e pentecostais. Essa é a mais nova e moderna mentira do Diabo, e parece que muitos têm acreditado nela" ${ }^{47}$. É flagrante a confusão instaurada. Confundiram o projeto de Deus com uma instituição histórica. Nesse sentido, Jüngen Moltmann esclarece melhor a real situação e aponta para o necessário redirecionamento. Para Moltmann, Deus vem ao mundo para renová-lo e seu projeto não é "encontrar abrigo em templos individualizados, nas catedrais, basílicas, mas em toda a sua criação"48. Podemos dizer que Deus até vai aos templos, mas, definitivamente, não é o lugar preferido dele. Ele quer estar com sua criação.

Outra questão que precisamos abordar é a união de Deus em Cristo com a humanidade: "A comunicação da vida nova por parte do Senhor ressuscitado e a união do Filho com toda a humanidade na sua encarnação são duas caras inseparáveis da mesma moeda"49. Assim como Cristo (Cabeça) está ligado à Igreja (Corpo), Ele também está ligado a todo gênero humano a partir da encarnação.

A kénosis (lit. esvaziamento) refere-se às limitações do Cristo encarnado sobre a Terra (Isaías 53). Envolveu o não-uso voluntário de alguns atributos divinos (Mateus 24.36) e o encobrimento da sua glória pré-encarnada

\footnotetext{
${ }^{45}$ BARRO, A. C. “A singularidade de Cristo no século XXI”. In: D. E. Price (org.). Que será dos que nunca ouviram? São Paulo: Vida Nova (2000) p.77-90, aqui p. 87.

${ }^{46}$ PRICE, D. E. "A importância da singularidade de Cristo para a prática missionária ou será que só Jesus salva?” In: (org.). Que será dos que nunca ouviram? São Paulo: Vida Nova (2000)

p. 9-40. Aqui p. 15 e 26 (grifos do texto).

${ }^{47}$ BARRO, A singularidade de Cristo no século XXI, p. 87.

${ }^{48}$ MOLTMANN, J. Quem é Jesus Cristo para nós hoje? Petrópolis: Vozes, 1996, p. 133.

${ }^{49}$ LADARIA, Jesucristo, salvación de todos, p. 14
} 
(João 17.5). Filipenses 2.7 registra que ele "a si mesmo se esvaziou". Assumir as limitações da humanidade foi um caminho de autoenfraquecimento que tinha como objetivo a comunicação com o mundo. Propomos que esse agir de Deus, o modelo kenótico, é um referencial necessário e procedurístico para a ação missionária da Igreja.

A encarnação de Deus foi desconcertante para as expectativas das comunidades religiosas no tempo de Jesus e permanece desconforme até hoje a muitos grupos. Quando na maioria das religiões e concepções humanas sobre a divindade o que se espera é um deus forte, invencível, invulnerável, na pessoa de Jesus, ao contrário, há uma identificação com o humano e com a fragilidade sem comparação. Ele identificou-se com o mundo de forma radical e, ao mesmo tempo, demonstrou uma diferença também radical (Fp 2.5-11).

Leonardo Boff reflete sobre o significado do Verbo que se fez carne:

Ele quis realmente ser como um de nós, como eu e como tu, menos no pecado: um homem limitado que cresce, que aprende e que pergunta; um homem que sabe ouvir e pode responder. Deus não assumiu uma humanidade abstrata, animal racional. Ele assumiu, desde o seu primeiro momento de concepção, um ser histórico, Jesus de Nazaré, um judeu de raça e de religião, que se formou na estreiteza do seio materno, que cresceu na estreiteza de uma pátria insignificante, que amadureceu na estreiteza de um povinho de vila interiorana, que trabalhou num meio limitado e pouco inteligente, que não sabia grego nem latim, as línguas da época, que falava um dialeto, o aramaico, com sotaque galilaico, que sentiu a opressão das forças de ocupação de seu país, que conheceu a fome, a sede, a saudade, as lágrimas pela morte do amigo, a alegria da amizade, a tristeza, o temor, as tentações e o pavor da morte e que passou pela noite escura do abandono de Deus. Tudo isso Deus assumiu em Jesus Cristo ${ }^{50}$.

Deus tornou-se ser humano. Em sua identificação com a humanidade, fez-se um de nós. Foi sujeitado às limitações humanas e padeceu nas estruturas sociais injustas do seu tempo. Joseph Aldrich afirma que "contudo, foi a realidade da clemência de Cristo que chamou a atenção à Sua deidade" ${ }^{51}$. A santidade e irrepreensibilidade de Jesus ditavam sua diferença dos demais. Essa constatação implica uma grande responsabilidade para a Igreja, pois mostra que as disciplinas

\footnotetext{
${ }^{50}$ BOFF, L. Encarnação: a humanidade e a jovialidade de nosso Deus. 4 ed. Petrópolis: Vozes, 1998, p. 13-14.

${ }^{51}$ ALDRICH, J. Amizade: a chave para a evangelização. São Paulo: Vida Nova, 1992, p. 49.
} 
da vida cristã são essenciais para que a ação missionária seja redentora. Esse Cristo inspirador e Senhor deve ser seguido pela Igreja-em-missão:

\begin{abstract}
Além de trazer a redenção, Cristo veio para torná-la visível, para revelar e comunicar o coração, a essência, o ser do Deus invisível. A Sua estratégia é instrumentativa porque a Sua missão era o protótipo da nossa: "Assim como tu me enviaste ao mundo, também eu os enviei ao mundo" (Jó 17.18; cf 20.21) ${ }^{52}$.
\end{abstract}

Se a missão de Jesus era o protótipo da nossa, faz-se necessário conhecer melhor seu modelo de atuação. A encarnação aponta para o desejo de Deus de comunicar-se de forma completa com um outro ser diferente dele. Mais do que isso, Leonardo Boff afirma que Deus "dignou-se dar-se de presente a alguém. Deus não quis ficar unicamente Deus. [...] Quis se dar: Deus dá Deus mesmo"53.

Essa entrega acontece de forma propositiva e interativa. A revelação não cai do céu como um manual de normas e preceitos de forma não-histórica. Nem se resume em uma nova religião para os homens. Deus envia a si mesmo. Habitou entre nós. "Ele está aí franzino para ficar junto de nós e nos libertar" 54 . Continua Leonardo Boff:

\begin{abstract}
Atentemos bem para a forma desta assunção: Deus não ficou no seu mistério indecifrável; ele saiu de sua luz inacessível e veio para as trevas humanas. Não permaneceu na sua onipotência eterna; ele penetrou na fragilidade da criatura. Não atraiu para dentro de si a humanidade; ele se deixou atrair para dentro da humanidade. Ele veio para o diferente dele; se fez aquilo que eternamente não era [...] Não temeu a matéria, não receou acolher a condição humana, por vezes trágica e, em muitos aspectos, absurda. Quem poderia imaginar que Deus se fizesse homem assim? $?^{55}$
\end{abstract}

Essa forma de atuação denominamos de modelo kenótico de Jesus. Ele desafia a condição humana e suas mazelas a uma viva esperança. Essa esperança radical, segundo Jung Mo Sung, nasce a partir de alguém que foi derrotado politicamente e abandonado até pelos seus amigos íntimos. Mas ele ressuscitou e nosso testemunho em esperança é qualitativamente diferente

\footnotetext{
${ }^{52}$ ALDRICH, Amizade, p. 28.

${ }^{53}$ BOFF, Encarnação, p. 9.

${ }^{54}$ BOFF, Encarnação, p. 8.

${ }^{55}$ BOFF, Encarnação, p. 11-12.
} 
da esperança que o sistema dominante pode oferecer ${ }^{56}$. O seguir a Jesus, que normalmente entendemos como discipulado cristão, é mais que tê-lo como inspiração. Consiste na relação com o próprio Cristo e, de acordo com David Bosch, o contexto dessa relação não é a igreja nem a sala de aula. O contexto do discipulado é precisamente o mundo ${ }^{57}$.

O modelo kenótico de Jesus deveria inspirar a missão. Uma prática missionária tem em Jesus ${ }^{58}$ o ponto de partida (modelo) e no Espírito Santo ${ }^{59}$, a certeza de renovação e de criatividade da ação. Imbuídos dessa premissa, a missão pode acontecer nos níveis esperados por Deus: "como agente eficaz para provocar mudança, não há nada que se compare ao amor. Seu poder transformador é maravilhosamente real e milagrosamente eficaz" ${ }^{\prime 0}$. O Deus trino é missionário. Move-se por amor. Concordamos com Jung Mo Sung quando afirma que Deus se revela ao mundo através do clamor que denuncia a falta de justiça, de solidariedade e do próprio sentido de humanidade, bem como através das respostas a esses clamores por intermédio de pessoas sensibilizadas "pelo Espírito que nos interpela para ações de solidariedade, de rebeldia e de transformação." 61

Além dessas implicações pastorais, precisamos tirar as consequências do que significa para o cristianismo ser uma religião da encarnação. A fé cristã assume não só que o ser humano foi criado por Deus, senão que foi criado à sua imagem e semelhança, chamado a ser Filho em Jesus, imagem perfeita do Pai, e a participar da gloria de sua ressurreição. Como afirma Ladaria, a encarnação do Filho confere à humanidade sua dignidade máxima. Como consequência, Jesus foi unido a todo ser humano ${ }^{62}$.

Sem o Filho encarnado e sem o Espírito, não se realiza o propósito salvador do Pai. A humanidade do Filho é a mediação humana da salvação de Deus. Por isso França Miranda afirma que "a ação divina passa necessariamente

\footnotetext{
${ }^{56}$ SUNG, J. M. “Cristianismo y 'otro mundo es posible”. In: Pasos. San José - Costa Rica: Segunda Época: DEI, mayo-junio, n. 125 (2006) p. 24-31. Aqui p. 27.

${ }^{57}$ BOSCH, D. J. Missão transformadora: mudanças de paradigma da teologia da missão. 2 ed. São Leopoldo: Sinodal, 2007, p. 93.

${ }^{58} \mathrm{O}$ Cristo encarnado e ressurreto, que dá motivos para celebrar e ter esperança. Cf. SUNG, Cristianismo y "otro mundo es posible" p. 31.

${ }^{59}$ José Comblin afirma que o acesso a Jesus se dá a partir de milhões de caminhos guiados pelo Espírito. COMBLIN, J. O tempo da ação: Ensaio sobre o Espírito e a História. Petrópolis: Vozes, 1982, p. 31.

${ }^{60}$ ALDRICH, Amizade, p. 24.

${ }^{61}$ SUNG, Cristianismo y "otro mundo es posible", p. 29.

${ }^{62}$ LADARIA, Jesucristo, salvación de todos, p. 76.
} 
pelo ser humano para nos atingir como salvação"63. Coloca-se em evidência a mediação humana. É Jesus quem faz essa ponte como Mediador. Há também uma mediação humana que todo homem precisa implementar, pois a salvação cristã não é espiritualizante. Deus é inacessível, misterioso e transcendente. No entanto, seu gesto salvífico permite ser experimentado e atingido por nós. Acontece no amor fraterno (estar-voltado-para-o-outro), quando este orienta a vida e constitui a atitude fundamental: "o amor autêntico a Deus não pode prescindir da experiência do amor humano autêntico" e "o nosso comportamento diante do nosso semelhante necessitado será critério decisivo para nossa salvação" "64. São fundamentais nosso testemunho e nossa coerência como cristãos:

A universalidade histórica de Jesus Cristo Salvador depende ainda do testemunho de vida de seus seguidores. É importante que Jesus Cristo seja proclamado não só nas confissões de fé, mas também na vivência salvífica dos cristãos. [...] São exatamente aqueles cristãos e cristãs que, no serviço escondido aos "últimos" da sociedade, tornam viva a pessoa salvífica de Jesus Cristo e confirmam de dentro da história a verdade da esperança cristã. ${ }^{65}$

A revelação máxima de Deus em Jesus encarnado nos possibilita, também, saber como responder a Deus. Toda sua vida e práxis iluminada anunciam a salvação e constituem-se boas novas. Nossa salvação depende de quanto assumimos como nossa Sua experiência histórica. Ele era movido pela atitude fundamental de obedecer ao Pai, de descentrar-se, de se entregar a Deus a aos homens do seu tempo. Doou-se para o outro, amou, entregou-se. A salvação que nos oferece precisa passar pelo mesmo caminho de entrega e serviço ao outro ${ }^{66}$. Somente assumindo sua vida podemos participar de sua ressurreição e de sua vitória. A fé-entrega (a Deus e ao próximo) é constitutiva do ser cristão ${ }^{67}$. Como viver com tanta intensidade a fé? quem é capaz de atualizar essa obra crística em nós? É o que vermos a seguir.

\footnotetext{
${ }^{63}$ MIRANDA, A salvação de Jesus Cristo, p. 138.

${ }^{64}$ MIRANDA, A salvação de Jesus Cristo, p. 132s.

${ }^{65}$ MIRANDA, O cristianismo em face das religiões, p. 71.

${ }^{66}$ RUBIO, O encontro com Jesus Cristo vivo, p. 182.

${ }^{67}$ MIRANDA, A salvação de Jesus Cristo, p. 73s.
} 


\section{A atuação universal do Espírito Santo}

O Espírito Santo é o Espírito de Deus e de Jesus Cristo. Com efeito, "nada se pode dizer do Espírito que não possa ser dito de Deus, nem se pode atribuir a Deus qualquer sentido que não se possa referir ao seu Espírito Santo. O Espírito é o aparecimento do amor divino no presente. Ele é Deus revelado em atos" $"$. O Espírito Santo garante que Deus está próximo do homem, presente de modo imediato e ativo na sua vida. Por isso, Deus não está distante nem é um ser exterior a este mundo. Ele manifesta a imediação e a atividade permanente da revelação de Deus. Mas as culturas e religiões acolhem essa revelação de Deus? E quando o fazem, chegam à plenitude da salvação oferecida unicamente em Jesus Cristo? Como conciliar essa revelação "pessoal" de Deus através do Espírito que sopra onde quer e a fé em Cristo? O conceito de Espírito deve ocupar lugar central na reflexão teológica, caso contrário obscurece os traços dinâmicos da ideia de Deus e deixa de captar a revelação continuada, presente e viva ${ }^{69}$.

A Escritura apresenta o Espírito como princípio da presença criativa de Deus (Gn 2.7) e como o meio com o qual as criaturas participam da vida divina e, também, da vida como tal ${ }^{70}$ (S1 104.29s). Da presença do Espírito de Deus dependem todas as criaturas, já que, de acordo com a compreensão cristã, o mundo foi criado "do nada". Na tradição, isso se expressa "ou pela afirmação de que Deus conserva o que criou, ou de que a cada instante o Criador repete seu sim originário a favor de sua criação"71. Independente disso, tanto a criação originária como a sua preservação apontam para um aperfeiçoamento da criação. Moltmann afirma: "tudo o que foi criado anseia por participar da gloria divina. Para isso se conserva o que foi criado"72. Assim, o Espírito é enviado constantemente às suas criaturas, dando-lhes vida e energia ${ }^{73}$.

Essa presença do Espírito preserva suas criaturas para sua perfeição. A fé e a esperança criam experiências levando o espírito humano a uma transcendência renovada $^{74}$. A partir dele os seres humanos são introduzidos na vida plena, sendo

${ }^{68}$ AULÉN, A fé cristã, p. 210.

${ }^{69}$ AULÉN, A fé cristã, p. 211.

${ }^{70}$ MIRANDA, Inculturação da fé, p. 96.

${ }^{71}$ MOLTMANN, J. A fonte de vida: O Espírito Santo e a teologia da vida. São Paulo: Loyola, 2002, p. 122.

${ }^{72}$ MOLTMANN, A fonte de vida, p. 122.

${ }^{73}$ MIRANDA, M. F. "A experiência do Espírito Santo: abordagem teológica”. In: M. F. Anjos (org.). Sob o fogo do Espírito. São Paulo (1998) p. 113-138.

${ }^{74}$ MOLTMANN, J. Teologia da esperança: estudos sobre os fundamentos e as consequências de 
o sentido profundo do Seu derramamento em dia de Pentecostes o de "levar à sua realização última a vida iniciada na criação" ${ }^{75}$. O Espirito é a certeza de que Deus não abandonou a sua criação:

Ele [Deus] participa do destino de suas criaturas por meio do Espírito imanente. Quando as criaturas sofredoras suspiram e gemem suspira e geme com elas o próprio Espírito de Deus, e clama por redenção. $\mathrm{O}$ Deus que sofre com suas criaturas por meio do Espírito que nelas habita constitui a firme esperança das criaturas ${ }^{76}$.

É esse Espírito quem flui na vida das pessoas, fazendo-as rogar pela vinda de Deus, o Deus que cria, vivifica, redime e salva. Mesmo quando pessoas nada mais podem além de suspirar pela redenção, silenciando depois do gemido, o Espírito já geme dentro delas e intervém em seu favor, como está registrado em Romanos 8.16: "O próprio Espírito se une ao nosso espírito para testemunhar que somos filhos de Deus" e nos versículos 26 e 27: "Assim também o Espírito socorre a nossa fraqueza. Pois não sabemos o que pedir como convém; mas o próprio Espírito intercede por nós com gemidos inefáveis, e aquele que perscruta os corações sabe qual o desejo do Espírito; pois, é segundo Deus que ele intercede pelos santos". Moltmann afirma: "A própria prece e o gemido pela vinda de Deus para dentro dessa vida cativa e desse mundo destruído procedem do Espírito e constituem seus primeiros sinais de vida"77.

O Espírito influencia o intelecto e também o inconsciente. Ele passa "não apenas pelo arbítrio, mas também pelos sentimentos e pelas pulsões de nossa vida. Nossa existência é santificada antes que façamos algo [...]"78. Ele permanece sempre junto das pessoas, quer o saibam e sintam, ou não. O Espírito Santo é o princípio da vida eterna, e permanece eternamente junto dos seus.

A atitude de Moltmann, orientada em direção ao futuro e informada pelas promessas de Deus, proporciona-nos uma visão da esperança intermediada pela obra transformadora de Deus. O Deus da ressurreição de Jesus Cristo fará uma nova criação de todas as coisas, renovando a vida pelo Espírito. Essa esperança em questão, como bem notou Alister McGrath, "não é individual, existencial nem particular. É a esperança pública, comum a toda criação,

uma escatologia cristã. 3 ed. Rev. Atual. São Paulo: Teológica; Loyola, 2005, p. 160.

${ }^{75}$ MIRANDA, Inculturação da fé, p. 96.

${ }^{76}$ MOLTMANN, A fonte de vida, p. 123.

${ }^{77}$ MOLTMANN, $A$ fonte de vida, p. 20.

${ }^{78}$ MOLTMANN, $A$ fonte de vida, p. 60. 
à medida que ela espera pela obra restauradora do 'Deus da esperança"'779. Assim, o mundo tem buscado essa esperança fora da tradição cristã, o que, para Moltmann, poderia ser revertido se a teologia cristã recuperasse sua escatologia e se voltasse para uma teologia da esperança ${ }^{80}$. Somente assim ela pode conseguir ser ouvida em uma cultura secular.

$\mathrm{O}$ fato de o Espírito estar presente no mundo, agir internamente nas pessoas e de ser fonte de vida da criação não significa que todos estão redimidos. A redenção não ocorre de forma inconsciente, e o Espírito não age independente da obra de Cristo. De fato, a verdadeira obra do Espírito é conduzir pessoas no caminho de Jesus Cristo e para dentro de seu discipulado. Concordamos com Moltmann que para o Novo Testamento "seguir a Jesus" é equivalente à "vida no Espírito" e que "reconhecer o Cristo ressuscitado e experimentar no Espírito da ressurreição as forças do próprio novo nascimento são um único momento". ${ }^{81}$ Ele acrescenta: "a orientação firme da fé não são as experiências interiores do Espírito, por melhores e importantes que sejam, mas sim a comunhão com Cristo, no viver, morrer e ressuscitar com Cristo" ${ }^{82}$

É o Espírito quem nos move para Deus, como "espírito de adoção" (G1 4.6 e Rm 8.14-16). A partir da perspectiva paulina, Luis Ladaria afirma que "só o Espírito é capaz de levar o homem à filiação divina em e com Cristo que constitui seu destino. Essa efusão do Espirito é também uma dimensão da novidade de Cristo, visto que dela depende" ${ }^{\text {" }}$. Miranda, por sua vez, observa que a ressurreição de Jesus já nos deixa entrever o que significa a própria e plena vida para o ser humano ${ }^{84}$. Nesse sentido, Moltmann entende a revelação com seu caráter de promessa, sempre anunciando a realidade futura ${ }^{85}$. O Espírito age com vistas ao futuro. E seu agir não se limita ao seio da igreja. Contudo, em seu agir no mundo, opera para a formação de uma "comunidade de vida e para a vida" a partir da fé no Ressuscitado (acolhimento da fé), apesar de reconhecermos que, dadas as diferenças culturais, a tematização será sempre distinta.

\footnotetext{
${ }^{79}$ McGRATH, A. Teologia sistemática, histórica e filosófica. São Paulo: Shedd, 2005, p. 635.

${ }^{80}$ MOLTMANN, Teologia da esperança, p. 55s.

${ }^{81}$ MOLTMANN, $A$ fonte de vida, p. 26 e p. 24, respectivamente.

${ }^{82}$ MOLTMANN, A fonte de vida, p. 39.

${ }^{83}$ LADARIA, Jesucristo, salvación de todos, p. 37, onde também observa que os Pais da Igreja, como Orígenes, por exemplo, uniram a novidade do Cristo ressuscitado com a novidade da graça do Espírito.

${ }^{84}$ MIRANDA, Inculturação da fé, p. 96 e também MIRANDA, A experiência do Espírito Santo, p. 113-138.

${ }^{85}$ MOLTMANN, Teologia da esperança, p. 115.
} 
Vimos anteriormente que a meta da autocomunicação de Deus somente é atingida se o ser humano acolher essa revelação. Essa afirmação é reiterada em toda a Bíblia. Naquela ocasião, não definimos como se dá esse acolhimento, apenas afirmamos que acontece "de algum modo". Essa abertura e possibilidade de caminhos que não conhecemos, atribuímos à ação do Espírito Santo no mundo. O significado universal de Cristo e sua mediação única estão necessariamente relacionados com a atuação do Espírito, que não conhece fronteiras. A resposta das pessoas em seu contexto cultural à provocação do Espírito indica que nenhuma cultura pode definir com exclusividade qual a melhor tematização da fé ou uma tematização padrão para as demais. O que podemos depreender é que a resposta ao convite do Espírito será sempre uma convocação para conformar-se como comunidade dos que creem. Assim, a revelação não estaria completa sem a igreja.

Essa "comunidade dos que creem", inclusiva e abrangente, é possível porque Cristo rompe todas as barreiras no poder do Espírito ${ }^{86}$. O evangelho resgatou o outro valorizando-o como pessoa igual. Ele foi anunciado por Jesus em categorias que valorizavam e dignificavam o ser humano. Com isso, quebraram-se barreiras de separação entre povos, culturas, classes, religiões, sexos. Por um lado, um convite tão acolhedor e promissor que atraía o mundo a uma nova vida. Por outro lado, esta nova comunidade em formação absorvia tão intensamente essa proposta que era impelida à sua continuidade. O modelo usado por Jesus foi de missão oniabrangente. No dizer de D. Bosch:

O que nos assombra reiteradamente é a inclusividade da missão de Jesus. Ela abarca tanto os pobres quanto os ricos, tantos os oprimidos quanto os opressores, tanto os pecadores quanto os devotos. Sua missão consiste em desfazer a alienação e em derrubar muros de hostilidade, em cruzar fronteiras entre indivíduos e grupos. [...] sua proclamação nada tem de coerção. Ela sempre permanece um convite. É possível imaginar um espírito missionário mais ardente e impelente? ${ }^{87}$

A base da fé cristã é a autocomunicação de Deus em Jesus Cristo. O fundamento teológico da missão só é possível se referir-se continuamente a essa base da fé. “A missão cristã dá expressão ao relacionamento dinâmico entre Deus e o

\footnotetext{
${ }^{86}$ OLIVEIRA, D. M. Missão cultura e transformação: desafios para a prática missionária comunicativa. São Leopoldo: Sinodal, Quito: CLAI, 2011, p. 57-59.

${ }^{87}$ BOSCH, Missão transformadora, p. 48-50. (grifos do autor).
} 
mundo, particularmente à maneira como ele foi retratado [...] de modo supremo, no nascimento, vida, morte, ressurreição, e exaltação de Jesus de Nazaré" ${ }^{88}$.

Esse projeto do Pai, que é "o Cristo em tudo e em todos" $(\mathrm{Cl} 3.11)$, realiza-se por obra do Espírito Santo. Inspirar-se no agir do Mestre é estar sob a ação do Espírito. Por isso, não é o caso de decifrar-se o que faria Jesus em cada situação, mas submeter nosso agir ao poder criativo do Espírito. J. Comblin expressa esse pensamento da seguinte forma:

Para nos levar ao Cristo, não há outro caminho senão o Espírito. Não existe nenhum caminho já traçado antecipadamente. O único caminho é o que o Espírito dispõe a cada instante, como que uma nova criação para cada um dentre nós. Não existe um caminho único: existem milhões de caminhos e o Espírito é a unidade de todos eles ${ }^{89}$.

Essa alternativa de caminhos em liberdade e regulada pela unidade do Espírito valoriza a diversidade. Seguir a Cristo não significa conformarem-se todos a um padrão rígido pré-estabelecido. Afirma J. Comblin: "cada qual imita tanto e melhor o Cristo quanto mais for original na criação de seu próprio modelo e na colocação de seus atos únicos" ${ }^{\prime 90}$. Essa variedade no reino de Deus é não só desejada, mas um pressuposto. Um modelo de missão relevante em nosso tempo precisa potencializar e reconhecer essas diferenças. Esse seria seu diferencial. Ainda com J. Comblin:

O Espírito não tem um modo próprio de agir: age fazendo agir os homens, isto é, movimentando o que é humano, o que existe de mais pessoal, original e único em cada homem. Seu agir é diverso e múltiplo. Se busca a unidade, é sempre para além da maior multiplicidade, no momento em que nenhuma força humana seria mais capaz de reencontrá-la ${ }^{91}$.

O Deus trino envia Jesus em missão reconciliadora. O Pai entrega o Filho por amor ao mundo. O Filho se recusa a usar de violência como um recurso e busca salvar o mundo. O Espírito move-se para interagir com o mundo, que ama profundamente, para convencê-lo da proposta redentora de Deus. J. A. Kirk afirma que é preciso refletir sobre

\footnotetext{
${ }^{88}$ BOSCH, Missão transformadora, p. 26, 27.

${ }^{89}$ COMBLIN, O tempo da ação, p. 31.

${ }^{90}$ COMBLIN, O tempo da ação, p. 31.

${ }^{91}$ COMBLIN, O tempo da ação, p. 33.
} 
a rejeição da violência, da prática de políticas não-violentas, da recusa de ser levado a aceitar estereótipos do inimigo e da rejeição da retaliação como sendo atitudes coerentes com a missão no caminho de Cristo e também como meios mais garantidos para se trazer uma mudança verdadeira ${ }^{92}$.

O sacrifício de Jesus é um meio de recuperar a harmonia nos relacionamentos. Seu evangelho da paz "é uma mensagem de valiosa reconciliação em que as injúrias causadas pela alienação são sanadas" ${ }^{93}$. Não se pode conceber uma prática missionária que desconsidere o problema da violência. Construir a paz, através da reconciliação genuína das partes hostis, é um aspecto fundamental das boas novas de Jesus Cristo.

Fica inteiramente claro que a prática missionária deveria seguir criativamente no Espírito o caminho de Jesus Cristo em um ministério de construir condições de reconciliação e paz ${ }^{94}$. No encontro com as religiões no mundo, muitos erros foram cometidos por ambos os lados. A reconciliação terá lugar quando o arrependimento for aceito por ambos, e o perdão for oferecido para uma relação de paz. Talvez, esperar que uma situação desse nível ocorra em um mundo tão conflituoso seria pedir muito. Mas cabe à igreja-em-missão, através de uma prática missionária comunicativa ${ }^{95}$, instigar esse processo. Por isso, a evangelização precisa ser integral, uma encarnação do evangelho em todas as dimensões da pessoa e em todo o seu contexto.

Mas não somente somos impelidos à missão. Mais que isso, a missão é um chamado para uma nova vida. Dados os muitos caminhos e possibilidades, a única constante é o Espírito Santo conduzindo-nos a uma nova vida. E isso afeta a todos. Para a igreja em particular, significa que temos de encontrar caminhos "da religião ao reino de Deus, da igreja ao mundo, da preocupação pelo próprio eu à esperança pelo todo" 96 .

É sabido que Jesus não trouxe ao mundo uma nova religião, mas uma nova vida. A obra do Espírito em consonância com a obra de Cristo será a de levar às pessoas essa possibilidade de nova vida. O Espírito, como fonte de vida, já atua sobre a criação. Mas a plenitude da vida está atrelada ao

\footnotetext{
${ }^{92}$ KIRK, J. A. O que é missão? Teologia bíblica de missão. Londrina: Descoberta, 2006, p. 192.

${ }^{93} \mathrm{KIRK}$, O que é missão? p. 193.

${ }^{94} \mathrm{KIRK}$, O que é missão? p. 210, 211.

${ }^{95}$ A proposta de uma "prática missionária comunicativa" foi publicada em OLIVEIRA, Missão cultura e transformação, e consiste em uma prática a partir do diálogo, da convivência e da fraternidade com vistas ao consenso.

${ }^{96}$ É o que explicava Cristoph Blumhardt, citado por MOLTMANN, A fonte de vida, p. 28.
} 
Ressuscitado, aquele a quem o Espírito deu vida e a compartilha com todos os que a Ele estiverem ligados.

O Espírito universaliza, interioriza e atualiza a obra de Cristo, inevitavelmente histórica, particular, contextualizada e limitada. É importante frisar que o âmbito da salvação do Espírito não é mais amplo que o de Jesus. Só há uma economia salvífica e está dada em Jesus. Foi iniciada com o Pai e o Espírito faz sentir os efeitos até os confins da terra. A humanidade glorificada de Cristo, espiritualizada e divinizada pelo Espírito enche todo o universo, e supera todas as limitações de tempo e espaço. ${ }^{97}$ Luis Ladaria pondera:

A universalidade de Cristo e a do Espírito vão juntas e não podem entender-se uma sem a outra. Sem o Espírito não chega a cumprir em nós a obra do salvador de todos. Tanto a relevância universal de Cristo como a relevância universal do Espírito são necessárias para a universalidade da salvação. ${ }^{98}$

E acrescenta:

Cristãos e não cristãos chegam a esta meta [filiação em Cristo] em virtude do dom do Espírito que nos associa ao único mistério pascal de Cristo, ainda que seja por caminhos diversos, que Deus conhece [...] Há uma única via, mas está aberta a todos..$^{99}$

O Concilio Vaticano II já havia apontado nessa ousada direção: "Devemos admitir que o Espírito Santo oferece a todos a possibilidade de se associar, de modo conhecido por Deus, ao mistério pascal" (GS 22).

O Espírito possibilita a experiência salvífica, embora não de modo reflexo ou temático ${ }^{100}$. De fato, de acordo com os relatos do Novo Testamento, em alguns casos Ele precedeu a proclamação explícita da mensagem cristã. Atos 10.19 nos informa que apareceram alguns homem à procura de Pedro e dá a entender que foram enviados pelo Espírito: "Entretanto, meditando ainda Pedro sobre a visão, disse-lhe o Espírito: Alguns homens estão aí, à tua procura". No mesmo capítulo, versículos 44 ao 47, registra: "Pedro estava ainda falando estas coisas, quando o Espírito Santo caiu sobre todos os que ouviam a Palavra. E os fiéis que eram da circuncisão, que tinham vindo com Pedro, ficaram estupefatos de verem que também sobre os gentios se derramara o dom do Espírito Santo,

\footnotetext{
${ }^{97}$ LADARIA, Jesucristo, salvación de todos, p. 141.

${ }^{98}$ LADARIA, Jesucristo, salvación de todos, p. 179.

${ }^{99}$ LADARIA, Jesucristo, salvación de todos, p. 180.

${ }^{100}$ MIRANDA, A salvação de Jesus Cristo, p. 210.
} 
pois ouviam-nos falar em línguas e engrandecer a Deus. Então disse Pedro: Poderia alguém recusar a água do batismo para estes, que receberam o Espírito Santo assim como nós?". Aqueles homens ainda não haviam "compreendido" a mensagem, mas o Espírito desceu sobre eles.

Consideramos, então, que práticas de outras religiões podem conter autêntica ação do Espírito Santo. Isso é verdadeiro, dado que só assim pôde ser ela expressa naquele contexto cultural e religioso. Não é propriamente o ato concreto (cultual, ético etc.) que se constitui em ação do Espírito, mas o que motiva o homem a realizá-lo. Há uma diversidade de realizações que podem ser de ordem religiosa ou não (por exemplo, pode suceder em ambientes secularizados). A questão central é que a ação do Espírito vai ser captada, experimentada, entendida, praticada e vivida em um contexto sociocultural e religioso. Por isso, há possibilidade de ação salvífica do Espírito de Cristo entre os membros de outras religiões, pois sendo Deus a salvação do homem, todo anseio de salvação se dirige a Ele, não importando a denominação que possam receber dos adeptos de tais religiões. A atitude fundamental de Cristo (amar) vivido em outra cultura pode se configurar de um modo que não nos é familiar. ${ }^{101}$

França Miranda acrescenta: "toda pessoa humana foi criada para acolher a Deus como o sentido último de sua vida, como sua realização suprema, numa palavra, como sua salvação"102. Deus nos cria para a salvação e a possibilita através da obra do Espírito Santo.

A ação universal do Espírito se derrama sobre todo o mundo. Pode ser comparado às aguas que fluem continuamente, como em Eclesiastes 1.7: "Todos os rios correm para o mar e, contudo, o mar nunca se enche: embora chegando ao fim do seu percurso, os rios continuam a correr"; ou com o vento, em João 3.8: "O vento sopra onde quer e ouves o seu ruído, mas não sabes de onde vem nem para onde vai. Assim acontece com todo aquele que nasceu do Espírito"; em Atos 2.17, ratifica sua vinda sobre a cada de Israel, e amplia para toda carne: "Sucederá nos últimos dias, diz o Senhor, que derramarei do meu Espírito sobre toda carne. Vossos filhos e vossas filhas profetizarão, vossos jovens terão visões e vossos velhos sonharão". O Espírito descerá sobre as criaturas, convidando-as para a vida plena em Jesus Cristo.

O seguimento de Jesus e a participação da sua vida são obra do Espírito, que no entendimento paulino aparece como "espírito vivificante": "Assim está escrito: o primeiro homem, Adão, foi feito alma vivente; o último Adão tornou-

${ }^{101}$ MIRANDA, A salvação de Jesus Cristo, p. 211.

${ }^{102}$ MIRANDA, A salvação de Jesus Cristo, p. 210. 
-se espírito que dá a vida" (1 Co 15.45); e, no joanino, como "intérprete da vida": "Com efeito, aquele que Deus enviou fala as palavras de Deus, pois ele dá o Espírito sem medidas" (Jó 3.34).

Para Moltmann, essa vida eterna do Espírito de Deus não é uma vida diferente da vida aqui, "mas sim a força por meio da qual a presente vida é transformada"103. Trata-se de um movimento de vida e de restauração que espalham coragem de viver e alegria de viver. A missio Dei é descrita em termos de missão de vida e consistiria no envio do Espírito Santo do Pai por intermédio do Filho a este mundo, para que este mundo não se arruíne, mas viva. O Espírito Santo traz vida: "vida total, vida plena, irrestrita, indestrutível, vida eterna". Missão, nesse sentido divino, não seria outra coisa senão movimento de vida e movimento de restauração, que espalhariam consolo e coragem de viver, soerguendo o que está prestes a morrer ${ }^{104}$.

Por essa razão a principal obra do Espírito na comunidade dos ressuscitados é promover a comunhão íntima e um habitar recíproco. Em 1 João 4.16 lemos: "E nós temos reconhecido o amor de Deus por nós, e nele acreditamos. Deus é Amor: aquele que permanece no amor permanece em Deus e Deus permanece nele". Aqui temos claramente Deus de modo divino em nós, e nós de modo humano nele. Moltmann observou que "na comunhão do Espírito Santo, o eterno Deus participa de nossa vida mortal, enferma, deficiente, e nós participamos da eterna vida de Deus. Essa comunhão recíproca é para nós uma fonte de poder inexaurível"105. Essa é a natureza do evangelho: Deus amou e aceitou-nos como somos. Por isso move-se para nos dar vida. Ele poderia salvar-nos por outras vias, mas escolheu o único caminho de salvação passando pela encarnação do Filho ${ }^{106}$. O centro da economia salvadora divina é a encarnação do Filho, e sua ação salvadora se realiza sempre por meio do seu Espírito Santo, nesse caso, Espírito de Vida.

\section{Conclusão}

Assumimos a universalidade da salvação e da obra do Espírito Santo em todas as culturas. Mas não perguntamos simplesmente onde Deus teria se

\footnotetext{
${ }^{103}$ MOLTMANN, A fonte de vida, p. 30.

${ }^{104}$ MOLTMANN, $A$ fonte de vida, p. 27.

${ }^{105}$ MOLTMANN, A fonte de vida, p. 75.

${ }^{106}$ LADARIA, Jesucristo, salvación de todos, p. 37.
} 
manifestado, mas quando e onde essa manifestação foi acolhida, revelando sua fidelidade, e junto a realidade de Deus. Nesse sentido, a prática missionária deve voltar-se para descobrir Jesus Cristo nos diferentes povos, a partir da atualização do Espírito. A atitude fundamental (sair-de-si-próprio) abre novos horizontes e possibilita emergir um Cristo que convida à conversão em cada povo (etnia), falando sua linguagem e expressando-se como eles. E isso faz referência ao futuro, ao novo, ao que vai acontecer. Também aqui está o real sentido da revelação: apontar para o futuro ${ }^{107}$. Deus interessado em dar vida, e vida com abundancia, não só aos humanos, mas a toda sua criação. $\mathrm{O}$ Espírito produzirá essa inquietude em nossos corações.

\section{Referências Bibliográficas}

ALDRICH, J. Amizade: a chave para a evangelização. São Paulo: Vida Nova, 1992.

AULÉN, G. A fé cristã. 2 ed. São Paulo: ASTE, 2002.

BARRO, A. C. “A singularidade de Cristo no século XXI”. In: D. E. Price (org.). Que será dos que nunca ouviram? São Paulo: Vida Nova (2000) p.77-90.

BOFF, L. América Latina: da conquista à nova evangelização. São Paulo: Ática, 1992.

. Encarnação: a humanidade e a jovialidade de nosso Deus. 4 ed. Petrópolis: Vozes, 1998.

BOSCH, D. J. Missão transformadora: mudanças de paradigma da teologia da missão. 2 ed. São Leopoldo: Sinodal, 2007.

COMBLIN, J. O tempo da ação: Ensaio sobre o Espírito e a História. Petrópolis: Vozes, 1982.

GEFFRÉ, C. Crer e interpretar: a virada hermenêutica da teologia. Petrópolis: Vozes, 2001.

W. SAAS. "O Deus trinitário está presente antes da chegada do missionário". In: Estudos Teológicos, v. 44, n. 2 (2004) p. 73-81.

$\overline{{ }^{107} \text { MOLTMANN, Teologia da esperança, p. } 61 .}$ 
KIRK, J. A. Oque é missão? Teologia bíblica de missão. Londrina: Descoberta, 2006.

LACOSTE, J-Y (dir). "Salvação". In: Dicionário Crítico de Teologia. São Paulo: Paulinas e Loyola, 2004.

LADARIA, L. F. Jesucristo, salvación de todos. Madrid: San Pablo, 2007.

McGRATH, A. Teologia sistemática, histórica e filosófica. São Paulo: Shedd, 2005.

MIRANDA, M. F. O cristianismo em face das religiões. São Paulo: Loyola, 1998.

. "A experiência do Espírito Santo: abordagem teológica". In: M. F. Anjos (org.). Sob o fogo do Espírito. São Paulo (1998) p. 113-138. 2001.

. Inculturação da fé: uma abordagem teológica. São Paulo: Loyola, . A salvação de Jesus Cristo: a doutrina da graça. São Paulo: Loyola, 2004.

MOLTMANN, J. Quem é Jesus Cristo para nós hoje? Petrópolis: Vozes, 1996. . A fonte de vida: O Espírito Santo e a teologia da vida. São Paulo: Loyola, 2002.

- Teologia da esperança: estudos sobre os fundamentos e as consequências de uma escatologia cristã. 3 ed. Rev. Atual. São Paulo: Teológica; Loyola, 2005.

OLIVEIRA, D. M. Missão cultura e transformação: desafios para a prática missionária comunicativa. São Leopoldo: Sinodal, Quito: CLAI, 2011.

PRICE, D. E. "A importância da singularidade de Cristo para a prática missionária ou será que só Jesus salva?” In: (org.). Que será dos que nunca ouviram? São Paulo: Vida Nova (2000) p. 9-40.

RUBIO, A. G. O encontro com Jesus Cristo vivo: um ensaio de cristologia para nossos dias. 14 ed. São Paulo: Paulinas, 2010.

. Unidade na pluralidade: o ser humano à luz da fé e da reflexão cristãs. 5 ed. São Paulo: Paulus, 2011. 
SENIOR, D. \& STUHLMUELLER, C. Os fundamentos bíblicos da missão. Santo André: Academia Cristã; São Paulo: Paulus, 2010.

SUNG, J. M. "Cristianismo y 'otro mundo es posible"”. In: Pasos. San José - Costa Rica: Segunda Época: DEI, mayo-junio, n. 125 (2006) p. 24-31.

David Mesquiati de Oliveira Doutorando em teologia PUC-Rio Professor no Mestrado Profissional em Ciências das Religiões e na graduação em teologia na Faculdade Unida de Vitória E-mail: david@faculdadeunida.com.br

Recebido em: 25/09/12 Aprovado em: 14/03/13 